\title{
LEVERAGE, GROWTH OPPORTUNITY DAN INVESTASI PADA PERUSAHAAN NON KEUANGAN YANG TERDAFTAR DI BEI
}

\author{
ANDRI RIANAWATI \\ Email: andri.rianawati@gmail.com \\ Rahmat Setiawan \\ Email: rahmatsetiawan@hotmail.com \\ Departemen Manajemen, Fakultas Ekonomi dan Bisnis, Universitas Airlangga
}

\begin{abstract}
Company's investment activities in Indonesia experienced significant fluctuations. Companies make the investments in order to enhance shareholder value. In connection with investment decision-making, company should consider the internal conditions, such as the condition of the company's bank debt or leverage conditions. Moreover, before making an investment decision, the company should consider the investment opportunities (growth opportunity). This study aims to identify the effect of leverage on investment and whether a company that has low growth opportunity has lower investment. This is seen by adding moderating variable-growth opportunity in leverage effect on investment, which is proxied by Tobin's $Q$ and sales growth. The samples used were non-financial companies listed on the Indonesia Stock Exchange in 2009 through 2013. The regression results showed significant negative effect of leverage on investment. This means that the leverage gives a negative impact on investment, the higher the leverage makes the investment lower. This happens because the bank debt raises investment restrictions on companies, thus higher bank debt will strengthen the restrictions on the investments made by the bank. Moderation model, of growth opportunity proxied by Tobin's $Q$ and Sales Growth, weakens the negative effect of leverage on investments in companies with low growth opportunity. This means, companies with low growth opportunities has weaker negative influence of leverage on the investment. This is because, companies that have low growth opportunity, have a lower profitable investment projects, so restrictions on investments made by the bank or keditor are looser.
\end{abstract}

Keywords: growth opportunity, investment, and leverage

\section{Latar Belakang}

Pada akhir tahun 2015 Indonesia akan memasuki era AEC (ASEAN EconomicCommunity), yang mana negara-negara ASEAN akan menyatu dalam berbagai hal seperti, perdagangan, export import serta aspek ekonomi lainya. Investasi dilakukan dalam upaya mengembangkan usaha dan juga perputaran modal, sehingga diharapkan melalui aktivitas investasi perusahaan dapat terus bersaing dalam persaingan yang semakin kompetitif.Investasi ada berbagai bentuk salah satunya adalah investasi dalam aset tetap. Gambar 1.1 dibawah merupakan grafik investasi aktiva tetap dan leverage perusahaan dari 


\section{Andri Rianawati Rahmat Setiawan}

tahun 2010 hingga 2013. Pada grafik dibawah investasi perusahaan memiliki grafik yang mengalami fkultuasi, artinya perkembangan investasi di Indonesia mengalamai peningkatan dan juga penurunan. Grafik leverage dibawah juga menunjukan adanya fluktuasi leverage yang diukur dari rasio utang bank. perkembanganleverage di Indonesia terbilang cukup stabil dengan tidak mengalami fluktuasi yang signifikan yang dapat dilihat pada grafik di bawah.

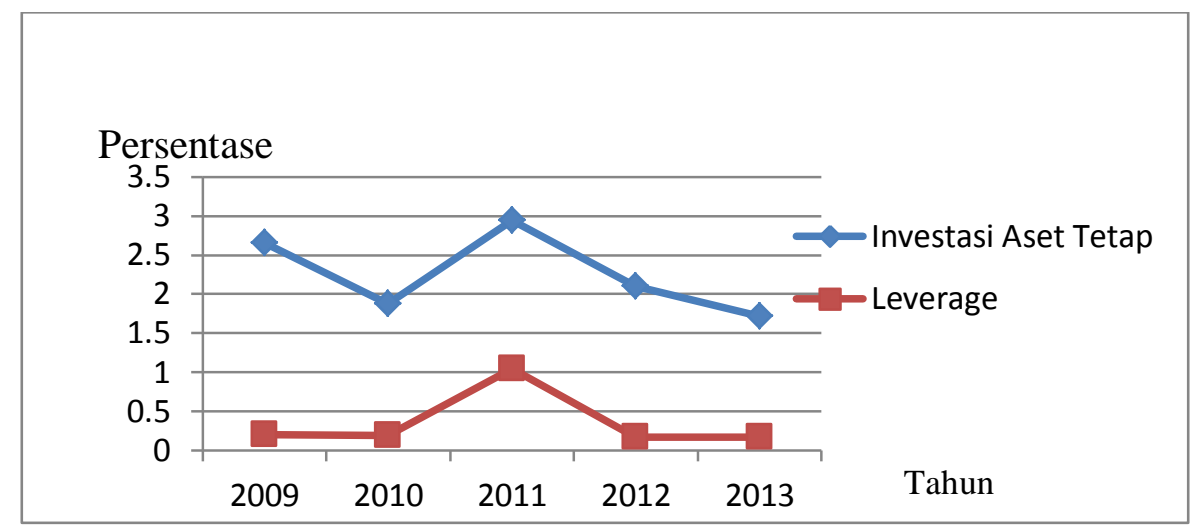

\section{Gambar 1.1 Investasi Aset Tetap dan Leverage Perusahaan periode 2009-2013}

Salah satu keputusan penting yang dihadapi oleh manajer kevangan adalah keputusan investasi, karena keptusan investasi erat kaitanya dengan keputusan yang lain seperti keputusan pendanaan dan keputusan dividen. Selain itu sebelum mangambil keputusan investasi perusahaan harus mempertimbangan kondisi internal perusahaan seperti leverage serta pertumbuhan perusahaan atau kesempatan investasi perusahaan. Saat perusahaan memiliki leverage, perusahaan memiliki beban tetap berupa bunga yang setiap periode harus dibayar. Beban tetap tersebut dapat mengurangi laba yang diperoleh serta menyebabkan pengurangan pada alokasi biaya lainya seperti investasi.

Pada penelitian ini leverage yang digunakan berasal dari utang bank. Peneliti ingin melihat bagaimana pengaruh utang bank terhadap investasi aktiva tetap perusahaan dan apakah utang bank berpengaruh untuk investasi dengan dilihat dari naik turunnya jumlah utang bank perusahaan.

Investasi perusahaan juga akan sangat dipengaruhi oleh seberapa besarnya growth opportunity atau peluang investasi perusahaan itu sendiri. Tobin's $Q$ dan pertumbuhan penjualandapat dipergunakan sebagai proksi untuk mengukur growth opportunity. Tingkat keuntungan tinggi yang dipersepsikan oleh calon investor akan meningkatkan nilai pasar dari sebuah perusahaan dan pada akhirnya akan meningkatkan rasio Tobin's $Q$ perusahaan tersebut. Perusahaan dengan growth opportunity yang tinggi cenderung memiliki 
kesempatan investasi yang besar, artinya perusahaan memiliki proyek profitable investment yang banyak.

Penelitian sebelumnya dilakukan Firth et al. 2008 yang mengahasilkan temuan bahwan utang berpengaruh negatif terhadap investasi. Selain itu Firth et al. juga menemukan hasil bahawa pengaruh negatif utang terhadap leverage lebih rendah pada perusahaan yang memiliki growth opportunity rendah. Untuk itu peneliti ingin mengeneliti pengaruh leverage yang dihitung berdasarkan rasio utang bank terhadap investasi aset tetap dengan memoderasikan growth opportunity yang diukur dengan Tobin's $Q$ dan juga pertumbuhan penjualanpada perusahaan non keuangan yang terdaftar di BEl.

Berdasarkan uraian latar belakang, maka pokok permasalahan yang diteliti dalam penelitian ini adalah

1. Apakah leverage berpengaruh terhadap investasi perusahaan?

2. Apakah growth opoortunity yang diukur dengan Tobin's $Q$ dan pertumbuhan penjualan memoderasi pengaruh leverage terhadap investasi?

\section{Landasan Teori}

\subsection{Pengertian dan Pengukuran Investasi Aktiva Tetap}

Investasi perusahaan yang dimaksud pada penelitian ini ditekankan pada perilaku investasi riil, yaitu investasi aktiva tetap perusahaan. Aktiva tetap merupakan aset memiliki usia relatif panjang. Aset tetap dapat berwujud (tangible) seperti truk dan komputer, atau tidak berwujud (intangible) seperti merek dagang dan hak paten, serta contoh lainya adalah mesin, peralahan, tanah dan gedung. (Ross, 2009:30; Sudana, 201 1:17). Peningkatan aktiva tetap sangat penting artinya bagi penyediaan sarana produksi maupun sarana penunjang yang diperlukan. Namun disisi lain, penambahan aktiva tetap juga akan meningkatkan biaya operasi, seperti penyusutan maupun yang berhubungan dengan biaya pemeliharaan aktiva tersebut, sehingga keputusan investasi perusahaan pada aktiva tetap harus diperhitungkan secara tepat dengan mempertimbangkan return dan cost.

\subsection{Pengertian dan Pengukuran Leverage berdasarkan Rasio Utang Bank}

Leverage adalah penggunaan aktiva dan sumber dana yang menimbulkan beban tetap bagi perusahaan. Penggunaan aktiva yang menimbulkan beban tetap disebut dengan operating leverage, sedangkan penggunaan dana dengan beban tetap disebut financial leverage. Financial leverage timbul karena perusahaan membelanjai kegiatan operasi dan investasi dengan dana yang menimbulkan beban tetap, yaitu berupa utang dan beban tetap berupa bunga (Sudana, 2011:157). Leverage dalam penelitian ini diukur berdasarkan rasio total utang bank terhadap total aset. Pendanaan kegiatan perusahaan 


\section{Andri Rianawati Rahmat Setiawan}

yang menggunakan utang bank menimbulkan beban tetap berupa bunga. Adanya utang bank sangat erat kaitanya dengan kegiatan perusahaan seperti investasi karena utang bank menimbulkan pembatasan (restriction) pada kegiatan investasi yang tertera pada perjanjian utang antara pihak bank sebagai kreditor dan pihak perusahaan sebagai debitur.

\subsection{Pengertian dan Pengukuran Growth Opportunity}

Growth opportunity atau peluang pertumbuhan perusahaan dapat didefinisikan sebagai peluang investasi perusahaan yang dapat meningkatkan nilai perusahaan di masa yang akan datang. Perusahaan yang memiliki growth opportunity tinggi berarti perusahaan tersebut memiliki proyek investasi dengan NPV positif banyak. Sebaliknya, pada perusahaan yang memiliki growth opportunity rendah maka perusahaan tersebut memiliki sedikit proyek investasi dengan NPV positif, atau sedikit memiliki proyek investasi yang menguntungkan.Growth opportunity dapat dilihat berdasarkan perhitungan Tobin's $Q$ dan pertumbuhan penjualan perusahaan.

\section{a. Pengertian dan pengukuran Tobin's $Q$}

Jiang et al. (2014) mendifinisikan Tobin's $Q$ adalah rasio dari nilai buku total utang ditambah nilai pasar ekuitas terhadap nilai buku total aset. Nilai Tobin's $Q$ yang tinggi berarti tingkat pertumbuhan perusahaan juga tinggi dimasa depan berdasarkan ekspektasi investor. Nilai Tobin's $Q$ yang tinggi menunjukkan prospek keuangan yang lebih baik, dengan kata lain tingkat keuntungan meningkat atau tingkat biaya modal yang menurun, dimana keduanya menjadi faktor yang akan meningkatkan peluang investasi yang dimiliki perusahaan. Perusahaan yang memiliki Tobin's $Q$ tinggi, berarti perusahaan tersebut memiliki growth opportunity yang tinggi pula, yang artinya perusahaan tersebut memiliki proyek investasi yang menguntungkan atau proyek investasi dengan nilai NPV positif dalam jumlah banyak.

\section{b. Pengertian dan Pengukuran pertumbuhan perusahaan}

Menurut Firth et al (2008) pertumbuhan penjualan perusahaan merupakan salah satu proksi dari growth opportunity. Pertumbuhan perusahaan yang tinggi memungkinkan perusahaan memiliki laba yang tinggi dan memberikan sinyal yang baik kepada kreditor untuk mendanai proyek investasi perusahaan, karena perusahaan dirasa mampu untuk membayar beban bunga atas utang yang diberikan dan laba yang tinggi akan memungkinkan perusahaan memiliki cash flow yang tinggi untuk mendanai proyek investasi. Perusahaan yang memiliki pertumbuhan penjualan tinggi, berarti perusahaan tersebut memiliki growth opportunity yang tinggi pula, yang artinya perusahaan tersebut memiliki proyek investasi yang menguntungkan atau proyek investasi dengan nilai NPV positif dalam jumlah banyak. 


\subsection{Faktor- fakłor Lain yang Mempengaruhi Investasi Perusahaan}

Menurut Firth et al. (2008) terdapat banyak faktor yang mempengaruhi investasi, antara lain cash flow dan perputaran aktiva tetap.

\section{a. Cash Flow}

Firth et al. (2008) menyatakan bahwa semakin besar cash flow yang dimiliki oleh perusahaan, maka semakin besar pula investasi yang dilakukan. Hal tersebut disebabkan juga karena perusahaan memilih untuk tidak membagikan dividen selama periode tertentu dan perusahaan akan mengalokasikan cash flow yang dimiliki perusahaan kepada kegiatan investasi. Cash flow pada penelitian ini adalah cash flow perusahaan dari aktivitas operasi. Arus kas operasi adalah kas yang berasal dari aktivitas bisnis perusahaan yang normal. Arus kas operasi merupakan indikator dari aktivitas operasi perusahaan dalam memperoleh kas yang cukup untuk memelihara kemampuan operasi perusahaan, melunasi utang, membayar dividen, dan melakukan investasi tanpa mengandalkan sumber pendanaan dari luar.

\section{b. Perputaran Aktiva Tetap}

Pengukuran perputaran aktiva tetap atau disebut dengan SFA (Sales to Fixed Asset), dalam penelitian ini adalah dengan membagi penjualan bersih (net sales) dengan aset tetap (net fixed assets). Hal ini mencerminkan perputaran aktiva tetap. Perputaran aktiva tetap mengukur efektifitas penggunaan aktiva tetap dalam menghasilkan penjualan bagi perusahaan (Sudana, 2011 :22). Dari besarnya penjualan dapat menunjukkan peluang laba rugi suatu perusahaan. Perusahaan yang memiliki penjualan bagus memungkinkan untuk memiliki laba yang bagus sehingga akan menghasilkan cash flow yang tinggi yang dapat digunakan untuk pendanaan kegiatan investasi.

\subsection{Pengaruh Leverage terhadap Investasi}

Leverage berpengaruh negatif terhadap investasi, hal ini berarti bahwa semakin tinggi leverage, semakin rendah investasi yang dilakukan oleh perusahaan. Pengaruh negatif leverage terhadap investasi disebabkan karena ketika sebuah perusahaan memperoleh utang dari sebuah bank, maka perusahaan akan menghadapi pembatasan (restriction) dalam aktivitas investasinya (Firth et al. 2008). Pembatasan tersebut muncul akibat adanya perjanjian utang yang ditandatangi oleh pihak perusahaan yang mendapatkan utang dan pihak bank yang memberi utang.Semakin besar utang bank yang dimiliki perusahaan, semakin besar pula pembatasan yang dihadapi oleh perusahaan tersebut dalam aktivitas investasinya, sehingga semakin rendah investasi yang dilakukan oleh perusahaan tersebut.

Pembatasan investasi yang diperoleh oleh perusahaan akbiat adanya utang bank membuat perusahaan memiliki ruang gerak dalam kegiatan investasi yang sempit. Hal ini 


\section{Andri Rianawati Rahmat Setiawan}

karena adanya pembatasan ini mengharuskan perusahaan untuk selalu lapor kepada bank terkait kegiatan investasi. Selain itu bank akan selalu memonitori kegiatan perusahaan sehingga manajer akan lebih berhati-hati dalam mengambil keputusan investasi. Hal ini membuat kegiatan investasi lebih rendah saat perusahaan memiliki utang bank.

Hasil penelitian empiris oleh Firth et al. (2008) pada perusahaan-perusahaan non keuangan di China menemukan bahwa leverage yang diukur dengan rasio utang bank berpengaruh negatif terhadap investasi. Pengaruh negatif leverage terhadap investasi pada perusahaan-perusahaan non keuangan di China disebabkan karena adanya pembatasan investasi yang dilakukan oleh pihak bank sebagai kreditur terhadap perusahaan-perusahaan yang meminjam dana kepadanya, sehingga semakin tinggi utang bank perusahaan semakin rendah pula investasi yang dilakukan.

$\mathrm{H}_{1}=$ Leverage berpengaruh negatif terhadap investasi

\subsection{Moderasi Tobin's Q pada Pengaruh Leverage terhadap Investasi}

Growth opportunities yang diukur dengan Tobin's $Q$ memperlemah pengaruh negatif leverage terhadap investasi pada perusahaan yang memiliki Tobin's $Q$ rendah. Hal ini berarti bahwa pengaruh negatif leverage terhadap investasi, lebih lemah pada perusahaan yang memiliki Tobin's $Q$ rendah dibanding pada perusahaan yang memiliki Tobin's $Q$ tinggi. Pengaruh negatif leverage terhadap investasi lebih lemah pada perusahaan yang memiliki Tobin's $Q$ rendah disebabkan karena perusahaan yang memiliki Tobin's $Q$ rendah mempunyai proyek investasi yang menguntungkan dalam jumlah yang lebih sedikit dibanding dengan perusahaan yang mempunyai Tobin's $Q$ tinggi. Oleh karena itu pembatasan (restriction) yang dilakukan oleh bank terhadap perusahaan peminjam yang memiliki Tobin's $Q$ rendah menjadi lebih longgar dibanding dengan perusahaan yang memiliki Tobin's $Q$ tinggi, dalam hal aktivitas investasi yang dilakukan oleh perusahaan peminjam (Firth et al., 2008).

Hasil penelitian empiris oleh Firth et al. (2008) pada perusahaan-perusahaan non keuangan di China menemukan bahwa pengaruh negatif leverage terhadap investasi lebih lemah pada perusahaan yang memiliki Tobin's $Q$ rendah. Pengaruh negatif leverage terhadap investasi lebih lemah pada perusahaan yang memiliki Tobin's rendah karena perusahaan yang memiliki Tobin's $Q$ rendah memiliki jumlah proyek investasi yang menguntungkan sedikit sehingga pembatasan (restriction) yang diberikan oleh pihak bank menjadi lebih longgar.

\section{$\mathrm{H}_{2.1}$ : Pengaruh Leverage negatif leverage terhadap investasi lebih lemah pada perusahaan yang memiliki Tobin's $Q$ rendah.}

\subsection{Moderasi Pertumbuhan Penjualan pada Pengaruh Leverage terrhadap Investasi}




\section{Jurnal Manajemen Teori dan Terapan \\ Tahun 8. No. 1, April 2015}

Growth opportunities yang diukur dengan pertumbuhan penjualan memperlemah pengaruh negatif leverage terhadap investasi pada perusahaan. Hal ini berarti bahwa pengaruh negatif leverage terhadap investasi, lebih lemah pada perusahaan yang memiliki pertumbuhan penjualan rendah dibanding pada perusahaan yang memiliki pertumbuhan penjualan tinggi. Pengaruh negatif leverage terhadap investasi lebih lemah pada perusahaan yang memiliki pertumbuhan penjualan rendah disebabkan karena perusahaan yang memiliki pertumbuhan penjualan rendah mempunyai proyek investasi yang menguntungkan dalam jumlah yang lebih sedikit dibanding dengan perusahaan yang mempunyai pertumbuhan penjualan tinggi. Oleh karena itu pembatasan (restriction) yang dilakukan oleh bank terhadap perusahaan peminjam yang memiliki pertumbuhan penjualan rendah lebih longgar dibanding dengan perusahaan yang memiliki pertumbuhan penjualan tinggi, dalam hal aktivitas investasi yang dilakukan oleh perusahaan peminjam (Firth et al., 2008).

Hasil penelitian empiris oleh Firth et al., (2008) pada perusahaan-perusahaan non keuangan di China menemukan bahwa pengaruh negatif leverage terhadap investasi lebih lemah pada perusahaan yang memiliki pertumbuhan penjualan rendah dibanding pada perusahaan yang memiliki pertumbuhan penjualan tinggi. Pengaruh negatif leverage terhadap investasi lebih lemah pada perusahaan yang memiliki pertumbuhan penjualan rendah disebabkan karena perusahaan yang memiliki pertumbuhan penjualan rendah memiliki jumlah proyek investasi yang menguntungkan sedikit sehingga pembatasan (restriction) yang diberikan oleh pihak bank menjadi lebih longgar.

\section{$\mathrm{H}_{2.2}$ : Pengaruh Leverage negatif leverage terhadap investasi lebih lemah pada perusahaan yang memiliki pertumbuhan penjualan rendah.}

\section{Metode Penelitian}

\subsection{Populasi dan Sampel}

Populasi dalam penelitian ini adalah seluruh perusahaan non keuangan yang terdaftar di Bersa Efek Indonesia pada tahun 2009 hingga 2013. Pengambilan sampel dilakukan dengan menggunakan metode carapurposive sampling, yaitu teknik pengambilan sampel dengan menggunakan batasan penelitian. Pada penelitian ini kriteria yang diambil adalah semua perusahaan non keuangan yang memiliki utang bank pada tahun 2009 hingga 2013. Kriteria yang digunakan dalam pengambilan sampel adalah sebagai berikut:

1. Tercatat sebagai perusahaan yang listing di BEl dan menerbitkan laporan keuangan tahunan pada tahun 2009-2013.

2. Perusahaan memiliki laporan yang lengkap dengan informasi yang berkaitan dengan pengukuran variabel. 


\section{Andri Rianawati \\ Rahmat Setiawan}

3. Laporan keuangan disajikan dalam mata vang rupiah.

4. Perusahaan yang memiliki utang bank.

\subsection{Definisi Operasi dan Pengukuran Variabel}

\section{Variabel Dependen}

1. Investasi

Investasi (INV) yang dimaksudkan dalam penelitian ini adalah investasi pada aktiva tetap perusahaan, yang menunjukan kenaikan atau penurunan aktiva tetap pada suatu periode dibanding periode sebelumnya dalam suatu perusahaan. Investasi aktiva tetap perusahaan diukur dengan menggunakan rumus

$\mathrm{I}_{\mathrm{it}}=\mathrm{NFA}_{\mathrm{it}}-\mathrm{NFA}_{\mathrm{it}-1}+\mathrm{D}_{\mathrm{it}}$

$I N V_{i t}=I_{i t} / N F A_{i t}$

Keterangan :

$\mathrm{I}_{\mathrm{it}} \quad=$ Net investment expenditure perusahaan i periode $\dagger$

$\mathrm{NFA}_{\mathrm{it}} \quad=$ Net fixed assets perusahaan i periode $\dagger$

$\mathrm{NFA}_{\text {it }-1}=$ Net fixed assets perusahaan i periode $\mathrm{t}-1$

$\mathrm{D}_{\mathrm{it}} \quad=$ Depreciation perusahaan i periode $\dagger$

$I N V_{i t} \quad=$ Investasi perushaan i periode $\dagger$

\section{Variabel Independen}

1. Leverage

Leverage(LEV) dalam penelitian ini diukur dengan rasio utang bank terhadap total aset. Perhitungan leverage dapat diperoleh dari rumus :

$$
\text { Leverage }(\mathrm{LEV})=\frac{\text { Total utang Bank }}{\text { Total Aset }}
$$

\section{Variabel Moderasi}

1. Tobin's $Q$

Tobin's $Q$ dalam penelitian ini merupakan proksi dari opportunity growth yang dihitung dengan total utang ditambah nilai pasar saham dibagi total aset. Variabel Tobin's $Q$ digunakan sebagai variabel moderasi dengan dummy Tobin's $Q$, yakni 1 untuk perusahaan 
yang memiliki nilai Tobin's $Q$ lebih rendah dari nilai median dan 0 untuk perusahaan yang memiliki Tobin's $Q$ lebih besar dari median.Tobin's $Q$ didapatkan dengan rumus :

$$
\text { Tobin's } Q=\frac{\text { Nilai Buku Total Utang }+ \text { Nilai pasar ekuitas }}{\text { Nilai Buku Total Aset }}
$$

2. Pertumbuhan Penjualan

Pertumbuhan penjualan (SG) merupakan proksi dari opportunity growth yang dihitung penjualan tahun $t$ dikurangi penjualan tahun $t-1$ dibagi penjualan tahun $t-1$. Variabel Pertumbuhan penjualan digunakan sebagai variabel moderasi dengan dummy pertumbuhan penjualan, yakni 1 untuk perusahaan yang memiliki nilai pertumbuhan penjualan lebih rendah dari nilai median dan 0 untuk perusahaan yang memiliki pertumbuhan penjualan lebih besar dari median. Perhitungan pertumbuhan penjualan dapat diperoleh dari rumus sebagai berikut:

$$
\text { Pertumbuhan penjualan (SG) }=\frac{\text { sales }_{t}-\text { sales }_{t-1}}{\text { sales }_{t-1}}
$$

\section{Variabel kontrol}

1. Cash Flow

Cash Flow (CF) yang digunakan dalam penelitian ini adalah cash flow operasional yang mencerminkan performa perusahaan selama satu periode.Cash flow dihitung dengan laba setelah pajak ditambah depresiasi dibagi total aset. Perhitungan cash flow perusahaan dapat diperoleh dari rumus

$$
\begin{aligned}
& C F_{i, t}=\frac{E A T_{i, t}+D_{i, t}}{T A_{t-1}} \\
& \text { Keterangan : } \\
& C F_{i, t} \quad=\text { Cash flow perusahaan i periode } \dagger \\
& E A T_{i, t}=\text { Earning after tax perusahaan i periode } \dagger \\
& D_{i, t} \quad=\text { Depreciation perusahaan i periode } \dagger \\
& T A_{t-1}=\text { Total Assets perusahaan i periode } \dagger
\end{aligned}
$$

\section{Perputaran Aktiva Tetap}

Perputaran aktiva tetap(SFA) merupakan jumlah penjualan yang tahun $t$ dibagi aset tetap tahun t. Perputaran aktiva tetap dalam penelitian ini dapat dihitung dengan menggunakan rumus

$$
S F A_{i, t}=\frac{\text { NetSales }_{t}}{\text { NetFixedAset }_{t}}
$$




\section{Andri Rianawati}

\section{Rahmat Setiawan}

\subsection{Metode Analisis Data}

Teknik analisis yang digunakan dalam penelitian ini adalah analisis regresi linier berganda untuk mengetahui pengaruh leverageterhadap investasi dengan variabel moderasi growth opportunity yang diproksikan dengan Tobin's $Q$ dan pertumbuhan penjualan. Model analisis dalam penelitian ini yaitu :

\section{- Model 1}

$I N V_{i, t}=\beta_{0}+\beta_{1} L E V_{i, t-1}+\beta_{2} Q_{i, t-1}+\beta_{3} D Q_{i, t-1} \times L E V_{i, t-1}+\beta_{4} C F_{t}+\beta_{5} S F A_{i, t-1}+\varepsilon_{i, t}$

\section{- $\quad$ Model 2}

$I N V_{i, t}=\beta_{0}+\beta_{1} L E V_{i, t-1}+\beta_{2} S G_{i, t}+\beta_{3} D S G_{i, t} \times l E V_{i, t-1}+\beta_{4} C F_{i, t}+\beta_{5} S F A_{i, t-1}+\varepsilon_{i, t}$

Keterangan

$$
\begin{aligned}
& I N V_{i, t} \quad \text { :Investasi aktiva tetap perusahaan i periode } \dagger \\
& \beta_{0} \quad \text { :Nilai Konstanta dari suatu persamaan } \\
& \beta_{1}, \beta_{2}, \beta_{3}, \beta_{4}, \beta_{5} \quad \text { :Nilai koefisien regresi dari masing-masing variabel } \\
& L E V_{i, t-1} \quad \text { :Leverage berdasarkan rasio utang bank perusahaan i periode t-1 } \\
& Q_{i, t-1} \quad \text { :Tobin's } Q \text { proksi dari growth opportunity perusahaan i periode t-1 } \\
& D Q_{i, t-1} \quad \text { Dummy Tobin's } Q \text { proksi dari growth opportunity perusahaan i } \\
& \text { periode } t-1 \text {, dimana } 1 \text { untuk perusahaan dengan nilai Tobin's } Q \\
& \text { kurang dari median dan } 0 \text { lebih dari median } \\
& S G_{i, t} \quad \text { :Pertumbuhan penjualan (Sales growth) proksi dari growth opportunity } \\
& \text { perusahaan i pada tahun ke- } \dagger \\
& D S G_{i, t} \quad \text { :Dummy pertumbuhan penjualan (sales growth) proksi dari growth } \\
& \text { opportunity perusahaan i periode } t \text {, dimana } 1 \text { untuk perusahaan } \\
& \text { dengan nilai sales growth kurang dari median dan } 0 \text { lebih dari median } \\
& C F_{i, t} \quad \text { :Cash flow operasional perusahaan i periode } \dagger \\
& S F A_{i, t-1} \quad \text { :Perputaran aktiva tetap (Sales to Fixed Asset) perusahaan i periode t- }
\end{aligned}
$$




\section{Hasil dan Pembahasan}

\subsection{Hasil Analisis Penelitian}

Tabel 4.3

Hasil Output Analisis Regresi Model 1 dan 2

Leverage terhadap investasi dengan moderasi Tobin's $Q$ dan Pertumbuhan Penjualan

\begin{tabular}{|c|c|c|c|c|c|}
\hline \multirow[t]{2}{*}{$\begin{array}{l}\text { MODEL 1/ } \\
\text { Variabel }\end{array}$} & Koefisien Regresi & Sig. $t$ & $\begin{array}{l}\text { Model 2/ } \\
\text { Variabel }\end{array}$ & $\begin{array}{c}\text { Koefisien } \\
\text { Regresi }\end{array}$ & Sig. $t$ \\
\hline & Unstandardized & & & Unstandardized & \\
\hline Konstanta & .715 & .000 & (Constant) & .802 & .000 \\
\hline LEV & -.361 & .049 & LEV & -.331 & .006 \\
\hline Q & .074 & .000 & SG & .070 & .000 \\
\hline DQ*LEV & .404 & .012 & DG*LEV & .381 & .006 \\
\hline CF & .054 & .001 & CF & .021 & .001 \\
\hline SFA & .016 & .000 & SFA & .008 & .000 \\
\hline R Square: & 0.106 & & R Square & 0,085 & \\
\hline
\end{tabular}

Sumber: data hasil output SPSS Statistics 22

\subsection{Pembahasan}

\subsubsection{Pengaruh Leverage terhadap Investasi}

Hasil penelitian ini menunjukkan bahwa leverage yang diukur dengan rasio utang bank berpengaruh negatif terhadap investasi. Hal ini terjadi baik pada model 1 maupun model 2. Berarti bahwa semakin tinggi tingkat pengunaan utang bank maka semakin rendah investasi yang dilakukan perusahaan. Pengaruh negatif leverage terhadap investasi dikarenakan perusahaan yang memiliki utang bank akan mendapatkan pembatasan (restriction) atas kegiatan investasi yang dilakukan perusahaan. Pembatasan investasi muncul karena adanya perjanjian utang yang dilakukan perusahaan atau pihak peminjam dengan pihak bank sebagai kreditor.Maka dari itu, semakin tinggi utang bank, semakin ketat pembatasan yang diberikan oleh pihak kreditor sehingga semakin rendah aktivitas investasi yang dilakukan perusahaan.

Perusahaan yang memiliki utang bank salah satunya adalah PT Indofood Tbk. PT Indofood Tbk memiliki utang bank jangka panjang pada beberapa bank, seperti BCA, DBS Indonesia, CIMB Niaga. Pembatasan yang berikan pihak kreditor atau bank antara lain seperti akuisisi dan investasi, penjualan atau pengalihan aset tetap, pengumuman dan pembagian dividen kas, penjualan dan pengalihan saham dan perubahan lingkup kegiatan usaha lainya.Pembatasan investasi akibat adanya utang bank juga terjadi pada PT Jaya Konstruksi Manggala Pratama Tbk. Pada contoh ini, perusahaan Jaya Konstruksi memiliki utang bank jangka pendek pada bank CIMB Niaga yang mengakibatkan perusahaan Jaya 


\section{Andri Rianawati Rahmat Setiawan}

Konstruksi harus menerima pembatasan dalam kegiatan investasi. Hal ini berarti aktivitas investasi yang dilakukan oleh PT Jaya Konstruksi harus seijin dan sepengetahuan Bank CIMB Niaga yang berperan sebagai kreditor.Maka dapat disimpulkan semakin tinggi utang bank akan membuat pembatasan investasi semakin tinggi dan mengakibatkan aktivitas investasi perusahaan menurun.

\subsubsection{ModerasiTobin's $Q$ pada Pengaruh Negatif Leverage Terhadap Investasi}

Pada model 1 diregresikan leverage yang diukur dengan rasio utang bank terhadap investasi aktiva tetap dengan dimoderasi oleh growth opportunity yang diukur dengan Tobin's Q. Hasil pada tabel 4.3 menunjukan variabel moderasi DQxLEV positif signifikan. Hal ini menunjukan bahwa pengaruh negatif leverage terhadap investasi lebih lemah pada perusahaan yang memiliki Tobin's $Q$ rendah. Maka semakin rendah Tobin's Qakan semakin lemah pengaruh negatif leverage terhadap investasi. Pengaruh negatif leverage terhadap investasi lebih lemah pada perusahaan yang memiliki Tobin's $Q$ rendah dikarenakan perusahaan yang memiliki Tobin's $Q$ rendah hanya memiliki proyek investasi menguntungkan dalam jumlah yang sedikit, sehingga pembatasan investasi yang dilakukan oleh pihak kreditor menjadi lebih longgar. Pembatasan investasi yang lebih longgar ini membuat pengaruh negatif leverage terhadap investasi menjadi lebih lemah. Maka dari itu dapat disimpulkan bahwa semakin rendah growth opportunity (Tobin's Q) semakin sedikit proyek investasi menguntungkan yang dimiliki perusahaan dan membuat semakin longgar pembatasan investasi yang dilakukan oleh kreditor, sehingga pengaruh negatif leverage menjadi lebih lemah.Hasil ini konsisten dengan studi dari Firth et al. (2005) yang dilakukan di China dengan sampel perusahaan listing yang terdaftar di China, Firth et al. (2005) menyatakan bahwa leverage berpengaruh negatif terhadap investasi lebih lemah pada perusahaan yang memiliki Tobin's $Q$ rendah.

Pengaruh negatif leverage terhadap investasi lebih lemah pada perusahaan yang memiliki Tobin's $Q$ rendah juga disebabkan karena perusahaan yang memiliki Tobin's $Q$ rendah relatif memiliki utang bank yang rendah, sehingga pembatasan (restriction) investasi yang diberikan lebih longgar dibanding perusahaan yang memiliki Tobin's $Q$ tinggi. Perusahaan yang memiliki Tobin's Qrendah berarti perusahaan tersebut memiliki growth opportunity rendah, perusahaan yang memiliki growth opportunity yang rendah relatif memiliki utang bank yang sedikit. Hal ini menyebabkan pembatasan (restriction) investasi lebih longgar, sehingga pengaruh negatif leverage terhadap investasi lebih lemah pada perusahaan yang memiliki Tobin's $Q$ rendah dibanding pada perusahaan yang memiliki Tobin's Q tinggi. 


\subsubsection{Moderasi Pertumbuhan Penjualan pada Pengaruh Negatif Leverage terhadap Investasi}

Pada model 2 diregresikan leverage yang diukur dengan rasio utang bank terhadap investasi aktiva tetap dengan menggunakan variabel moderasi growth opportunity yang diukur dengan pertumbuhan penjualan. Hasil pada tabel 4.4 menunjukan variabel moderasi DSGXLEV positif signifikan. Hal ini berarti pengaruh negatif leverage terhadap investasi lebih lemah pada perusahaan yang memiliki pertumbuhan penjualan rendah. Maka semakin rendah pertumbuhan penjualan membuat pengaruh negatif leverage terhadap investasi menjadi lebih lemah. Pengaruh negatif leverage terhadap investasi lebih lemah pada perusahaan yang memiliki pertumbuhan penjualan rendah dikarenakan perusahaan yang memiliki pertumbuhan penjualan rendah memiliki proyek investasi yang menguntungkan dalam jumlah sedikit sehingga pembatasan investasi yang dilakukan oleh kreditor menjadi lebih longgar. Hal ini membuat perusahaan lebih leluasa dalam melakukan aktivitas investasi.Maka dari itu, pengaruh negatif leverage terhadap investasi menjadi lebih lemah pada perusahaan yang memiliki growth opportunity (pertumbuhan penjualan) rendah.Hasil ini mendukung penelitian Firth et al. (2008).bahwa pengaruh negatif leverage terhadap investasi lebih lemah pada perusahaan yang memiliki growth opportunity (pertumbuhan penjualan) rendah.

Pengaruh negatif leverage terhadap investasi lebih lemah pada perusahaan yang memiliki pertumbuhan penjualan rendah juga disebabkan karena perusahaan yang memiliki pertumbuhan penjualan rendah relatif memiliki utang bank yang rendah, sehingga pembatasan (restriction) investasi yang diberikan lebih longgar dibanding perusahaan yang memiliki pertumbuhan penjualan tinggi. Perusahaan yang memiliki pertumbuhan penjualan rendah berarti perusahaan tersebut memiliki growth opportunity rendah, perusahaan yang memiliki growth opportunity yang rendah relatif memiliki utang bank yang sedikit. Hal ini menyebabkan pembatasan (restriction) investasi lebih longgar, sehingga pengaruh negatif leverage terhadap investasi lebih lemah pada perusahaan yang memiliki pertumbuhan penjualan rendah dibanding pada perusahaan yang pertumbuhan penjualan tinggi.

\subsubsection{Pengaruh Variabel Kontrol terhadap Investasi}

\section{Cash Flow}

Variabel kontrol yang digunakan dalam penelitian ini cash flow dan perputaran aktiva tetap baik pada model 1 maupun model 2. Hasil pada tabel diatas cash flow memiliki tingkat siginifikansi 0,001 pada model 1 dan juga pada model 2, serta memiliki koefisien regresi positif, hal ini menunjukan bahwa cash flow memiliki pengaruh positif signifikan 


\section{Andri Rianawati Rahmat Setiawan}

terhadap investasi baik pada model 1 maupun model 2. Hal ini berarti semakin tinggi cash flow yang dihasilkan perusahaan semakin tinggi pula investasi yang dilakukan. Hal ini disebabkan karena, pada perusahaan yang memiliki cash flow tinggi berarti perusahaan memiliki cadangan kas yang cukup untuk mendanai aktivitas investasi perusahaan.Sehingga perusahaan yang memiliki cash flow tinggi, memiliki aktivitas investasi yang tinggi pula.

\section{Perputaran Aktiva Tetap}

Hasil regresi yang dilakukan pada model 1 dan model 2 menunjukan bahwa perputaran aktiva tetap berpengaruh positif terhadap investasi.Artinya semakin tinggi perputaran aktiva tetap yang dihasilkan perusahaan semakin tinggi pula investasi yang dapat dilakukan perusahaan.Hal ini dikarena pada perusahaan yang memiliki perputaran aktiva tetap tinggi maka perputaran aktiva tetap dalam menghasilkan penjualan bagus sehingga dapat menghasilkan laba yang tinggi.Perusahaan yang memiliki laba tinggi dapat menghasilkan cash flow yang tinggi pula, cash flow ini dapat digunakan untuk pendanaan kegiatan investasi, sehingga aktivitas investasi menjadi meningkat.Sehingga perusahaan yang memiliki perputaran aktiva tetap tinggi, memiliki aktivitas investasi yang tinggi pula.

\section{Simpulan}

Berdasarkan hasil analisis data dan pembahasan yang sudah diuraikan sebelumnya, dapat ditarik kesimpulan sebagai berikut :

1. Leverage yang diukur dengan rasio utang bank terhadap total aset memiliki pengaruh negatif terhadap investasi aktiva tetap perusahaan. Leverage berpengaruh negatif terhadap investasi berarti semakin besar utang bank yang dimiliki perusahaan, semakin rendah investasi yang dilakukan perusahaan. Pengaruh negatif leverage terhadap investasi dikarenakan perusahaan yang memiliki utang bank mendapatkan pembatasan investasi yang diberikan oleh kreditor sehingga hal ini dapat menurunkan investasi perusahaan.

2. Pengaruh negatif leverage terhadap investasi lebih lemah pada perusahaan yang memiliki growth opportunity rendah, yang diukur berdasarkan Tobin's $Q$ dan pertumbuhan penjualan. Hal ini, berarti semakin rendah growth opportunity perusahaan, mengakibatkan semakin lemah pengaruh negatif leverage terhadap investasi. Pengaruh negatif leverage terhadap investasi lebih lemah pada perusahaan yang memiliki growth opportunity rendah terjadi karena pada perusahaan yang memiliki growth opportunity rendah memiliki proyek investasi menguntungkan yang sedikit sehingaa pembatasan yang dilakukan oleh kreditor menjadi lebih longgar. 


\section{DAFTAR REFERENSI}

Ahn, Seoungpil, David J.Denis and Diane K. 2006.Leverage and Investment in diversity Firms.Journal of Financial Economics.No.79, pp.317-337.

Aivazian.A.V., 2005. The impact of leverage on firm investment: Canadian Evidence, Journal of corporate Finance, No.11, pp.277-291.

Anshori, Muslich dan Sri Iswati., 2009.Metodologi Penelitian Kuantitatif: Surabaya, Pusat Penerbitan dan Percetakan UNAIR

Brigham, Eugene F., and Louis C. Gapensky. 1996. Intermediate Financial management, fifth Edition, foet Worth: The Dryden Press: Harcour Brance Collage Publishers

Firth, Michael . 2008. Leverage and investement under a state-owned bank lending environment: evidence from China, Journal of Corporate Finance, No.14, pp.642-653.

Ghozali, imam. 2006. Aplikasi Analisis Multivariate dengan Program SPSS. Semarang: Badan Penerbit Universitas Diponegoro

Hidayat, Riskin. 2010. Keputusan Investasi dan Financial Constraint: Studi Empiris pada Bursa Efek Indonesia. Buletin Ekonomi Moneter dan Perbankan, Vol. 12 No. 4, Hal.445468.

IDX. 2009.Indonesian Stock Exchange. Jakarta, Indonesia

-----2010.Indonesian Stock Exchange. Jakarta, Indonesia

-----.2011.Indonesian Stock Exchange. Jakarta, Indonesia

-----2012.Indonesian Stock Exchange. Jakarta, Indonesia

-----2013.Indonesian Stock Exchange. Jakarta, Indonesia

Jiang, Wei and Yeqin Zeng.State ownership, bank loans, and corporate investment.International Review of Economic and Finance, No.32, pp.92-116.

Rianawati, Andri dan Rahmat Setiawan, 2015. Leverage,, Growth Opportunity dan Investasi Perusahaan Non Keluarga Yang Terdaftar di BEl, Program Studi S1 Fakultas Ekonomi dan Bisnis Universitas Airlangga, 126.

Santoso, Singgih. 2014. SPSS 22 from Essential to Expert Skills. Jakarta: Penertbit Elex Media Komputindo

Sarwono, Jonathan. 2013. 12 Jurus Ampuh SPSS untuk Riset Skripsi. Jakarta: PT Elex Media Komputindo

Sudana, I Made. 2011. Manajemen Keuangan Perusahaan Teori dan Praktik, Jakarta: Penerbit Erlangga

Ross, Westerfield and Jordan. 2009. Pengantar Keuangan Perusahaan, Jakarta: Penerbit Salemba Empat 